\title{
Interdisciplinary Collaborative Research for Professional Academic Development in Higher Education
}

\author{
Elizabeth Johnston, EdD \\ University of Phoenix, Phoenix, Arizona, United States \\ (iD https://orcid.org/0000-0003-0695-1475 \\ Cheryl Burleigh, EdD \\ Brandman University, Irvine, California, United States \\ (iD) https://orcid.org/0000-0003-2393-5477 \\ Andrea Wilson, $\mathrm{PhD}$ \\ Walden University, Minneapolis, Minnesota, United States \\ (iD https://orcid.org/0000-0002-1471-654X
}

Contact: andrea.wilson6@mail.waldenu.edu

\begin{abstract}
Although faculties are more diverse, decentralized, and increasingly isolated in technology-supported modern universities, effective technology use can also foster faculty professional academic development and collegiality. This scoping literature review applied Cooper's systemic review model and a categorical content analysis technique targeting decentralized collaborative research teams in higher education. Findings indicate technology supports formal and informal university and nonuniversity networks, as well as various collaborative research structures; all contributing to professional academic development. Shared attributes of successful collaborative online teams include a sense of social presence, accountability, institutional and team leadership. Collaborative teams are integral to research and allow more faculty members to contribute and benefit from professional academic development through scholarship. Collaborative team research should be investigated further to understand and promote cross-discipline and cultural collaboration potential for research and professional academic development possibilities with special attention given to opportunities for women, online, and adjunct faculty.
\end{abstract}

Keywords: professional academic development; higher education pedagogies; interdisciplinary research teams; networking; adjunct faculty; collaboration; technology

Submitted: March 2, 2020 | Accepted: April 2, 2020 | Published: May 22, 2020

\section{Recommended Citation}

Johnston, E., Burleigh, C., \& Wilson, A. (2020). Interdisciplinary collaborative research for professional academic development in higher education. Higher Learning Research Communication, 10(1), 62-77.

DOI: $10.18870 /$ hlrc.v10i1.1175 


\section{Introduction}

Technology is transforming higher education and requiring faculty members to assume new roles and duties (Renner, 2017). The transformative effect of technology changes many dimensions of faculty life such as teaching environments, student contact, and tenure. In addition, technology supports the frequent collaboration needed to resolve increasingly complex problems (Siemens et al., 2014), and access to technology makes remote or international team member research possible (Kosmützky, 2018). Scholarly collaboration as empowered by technology could be an essential aspect of faculty professional development in the 21st-century higher education. For example, an academic professional development initiative occurred through a collaborative writing group formed to develop skills in a technology-supported environment where members could encourage and coach others both as colleagues and writers (Turner et al., 2014). Technology support made the collaboration possible in an asynchronous environment that crossed geographical boundaries.

Online communities of practice share ideas, collaborate easily, and support rapid production and dissemination of research because technology makes connections possible. High-performing collaborative research teams in higher education, either in the United States or internationally, can surpass individual efforts in research production output based on team dynamics and diversity (Cheruvelil et al., 2014; Kosmützky, 2018). Collaboration is a productive strategy for publishing research, an urgent concern for faculty recognition, tenure and promotion (Burroughs, 2017). In turn, new research enhances both individual and community practices of teaching and learning, best described as the realization and embodiment of practical professional development (Leibowicz, 2014). Collective or individual professional or academic developers play important roles in supporting development for early career academics as well as growth for senior faculty members (Matthews et al., 2014). Merging technology and diverse team collaboration is an essential aspect of research skills development for faculty members in 21st-century higher education. The present literature review may provide professional or academic developers with valuable insights into faculty development in technology supported collaborative environments.

Faculty members miss important opportunities to develop connections and hone skills when they do not engage in collaborative research (Misra et al., 2017). Faculty collaborative opportunities differ by disciplines (Burroughs, 2017; Kosmützky, 2018; Siemens et al., 2014); and science, technology, engineering, and math faculty are more likely to engage in collaborative research than colleagues in humanities or social sciences (Kosmützky, 2018). However, individual researchers are more common across all disciplines in higher education than collaborative teams (Kosmützky, 2018), especially outside the disciplines of science, technology, engineering, and math; health; and business. Other discrepancies in collaborative research opportunities exist for women and particularly women of color when compared to men (Misra et al., 2017). Findings from another study indicated male faculty members frequently had more collaborative research partners within their departments than female colleagues, but women and men had the same number of research partners external to their departments (Falci et al., 2014).

College and university demographics are changing and reflect higher numbers of adjunct or part time faculty members (Eddy \& Garza Mitchell, 2012). In American universities, estimates place one third to two thirds of university faculty as online adjuncts in a decentralized educational model (Schieffer, 2016). Others place numbers of adjunct faculty at 50\% or more (Caruth \& Caruth, 2013). The American Association of University Professors (2018) estimated that adjuncts or contingent positions with limited long-term university commitment comprised 50\% of all faculties. Although reported as the most rapidly growing demographic group in academic communities, adjunct faculty members have limited access to collaborative research opportunities (Dailey-Hebert et al., 2014). In response to the changing faculty demographics, Schieffer (2016) called on higher education leaders to provide support and development for online adjuncts. 
University leaders may require adjunct faculty to publish (Schieffer, 2016) despite their contingent status and offering few opportunities for collaborative research. Universities often hire large numbers of adjunct faculty and are partly evaluated on faculty scholarly accomplishments. Adjunct faculty members, a majority in some private or for-profit universities, need to show evidence of scholarship to insure more favorable appraisals of the university. Subsequently, universities with higher numbers of contingent faculty are changing to include specific publishing requirements for faculty. Professional development and support are needed for adjunct faculty with practice-based proficiency who lack research expertise to meet increasingly rigorous publishing goals. Collaborative research teams could provide professional development and other individual and system wide benefits. Essentially, collaborative research is a project-based learning opportunity that supports professional development although rarely recognized as such.

In summary, collaborative research may build a sense of greater equity in decentralized higher education environments (Misra et al., 2017) and provide newer faculty with valuable mentoring and role models (Burroughs, 2017). Technology is transforming personal and professional systems and relationships for higher education faculty and supporting new professional development models needed for successful execution of professional and collegial roles (Renner, 2017). The intention of the present study was to explore the literature on how technology supports collaborative research in fields, disciplines, or instances in which collaborative research was and remains rare.

\section{Conceptual Framework and Literature Review}

The structure of this scoping literature review incorporates elements of content analysis within a larger systematic literature review which allowed for envisioning a conceptual map that identified saturated and undersaturated targets in the current literature (e.g., Anderson et al., 2008). Traditionally, a scoping review is exploratory in nature and may include peer reviewed articles and other sources (S. Cooper et al., 2019). The review was guided by emergent concepts and topics that proliferate the body of existing literature. As inquiry into and analysis of the existing literature are conducted, key topics rise to the surface and act as a guiding force behind the ongoing review forming the conceptual framework for the inquiry. In this study, these topics included technology, sharing and collaborating, and faculty membership.

\section{Technology}

Technology supports new research structures that will bring change to the academic world (Kosmützky, 2018). As a result of changes in the use of technology, research practices are evolving in response to new possibilities which are energized by technology (Vabø et al., 2016). Traditionally, scholars learned from and generated new knowledge via research produced by engaging in a scholarly community (Stewart, 2015). Technology-enhanced research networks allow diverse groups of researchers to pool resources, compare ideas, and discuss emerging trends (Jamali et al., 2014). For example, ResearchGate is an emerging but wellknown community where researchers share new work in nascent or published form.

\section{Sharing and Collaborating}

Sharing and collaborating with a team of researchers allows individuals who might not otherwise be able to conduct new research receive the support needed for research development while functioning with a productive network. In one instance, a Tennessee Board of Regents Office of Academic Affairs project engaged researchers from three campuses as participants in the Critical Conversations Research Network (Renner, 2017). Participating faculty members worked toward achieving similar goals, engaged with others to create and cocreate new knowledge through research, and shared skills and resources existing within the network. As a result of sharing and collaborating, faculty roles were changing through a new mechanism for scholarly output. Collaborative research allows isolated individuals the opportunity to create and manage research 
projects, with more than one author, whereby members publish and disseminate their work together (Jamali et al., 2014). Building collaborative communities to support higher education pedagogies, where full-time and adjunct faculty members study improved teaching and learning practices is rare (Eddy \& Garza Mitchell, 2012).

\section{Faculty Members}

Faculty members play pivotal roles in any educational transformation (Boyer, 1996). The implementation of 21st-century technology is transforming faculty members' ability to communicate within and beyond the research team. With technology, faculty members can distribute knowledge that will transform for the better the existing structures within and around universities (Kosmützky, 2018). A technology-powered transformation of universities begins with enhanced faculty activities that are consistent with Boyer's expanded model of scholarship (Eddy \& Garza Mitchell, 2012). Boyer's domain of discovery is most closely associated with effectively using technology via collaborative research teams of faculty committed to developing new knowledge through research.

\section{Purpose}

The purpose of the present scoping literature review was to systematically explore, categorize, and chart the available research related to small collaborative research teams composed of faculty, students, or staff in higher education, humanities, and social sciences or adjunct faculty in any field. In higher education, the emphasis was pedagogies. Additional purposes were to define gaps in the current literature, provide a synthesis of insights gained about structure and team processes, and stimulate dialogue among peers.

\section{Research Questions}

The research questions allowed an exploration of descriptive data using a categorical reasoning approach. The research question and subquestions guiding this study included the following:

Research Question: What technologically powered connectivity approaches are used to support international and domestic collaborative research in higher education, social sciences, and humanities or for adjunct faculty?

Subquestion 1: How are collaborative research teams using technology to support the generation of new knowledge?

Subquestion 2: What attributes and organizational frameworks do successful collaborative research teams demonstrate?

\section{Method}

This literature review was organized using H. M. Cooper's (1998) research framework that could synthesize literature for varying purposes. H. M. Cooper $(1985,1986,1988)$ previously developed taxonomies to organize and categorize literature from various perspectives and then developed a research framework to support synthesis of literature (H. M. Cooper, 1998). Cooper's research framework was used in reviews of traditional scholarly sources in studies such as Avella and colleagues (2016) or in studies such as the one by Kebritchi and Hirumi (2008), in which the research framework was adapted to analyze electronic games for pedagogical content. H. M. Cooper's (1998) research framework for literature synthesis included directions on how to (a) formulate the problem, (b) collect data, (c) judge data for fit or alignment to the purpose of the study, (d) appraise and interpret the data determined to be relevant, and e) categorize, assemble, and present the products. To answer the research questions, categorical reasoning, associated with content analysis, was 
applied to each article's text in the study to insure a systematic analysis of frequencies, structures, and relationships (Mayring, 2000).

\section{Formulating the Problem}

The focus of the present study was on fields, disciplines, or instances where distance collaborative research was infrequent or missing as opportunities to foster academic professional development for faculty researchers. Documentation of limited collaborative research projects was found for the humanities (Burroughs, 2017) and social sciences (Woolley et al., 2015). Kosmützky (2018) found fewer collaborative, international research teams in the social sciences, humanities, and higher education and characterized those fields as dominated by individual researchers. Adjunct faculty members were less frequently involved in collaborative research projects than full-time faculty (Schieffer, 2016).

Formulating the problem was conducted by completing a broad, cursory review of the literature consistent with H. M. Cooper's (1998) Step A. The initial review of the literature revealed little is known about how research teams in these fields use technology-supported systems to develop, communicate, write, and publish research articles (Jamali et al., 2014). More research is needed to understand how technology may support collaborative research where opportunities have been limited.

\section{Sampling and Data Collection}

\section{Systematic search of the literature to collect data}

Sampling data collection was completed incorporating H. M. Cooper's (1998) Step B and conducted in EBSCOhost, ProQuest, Sage Knowledge Journals, and ResearchGate. These databases were selected because of the wide variety of journals that were included. ResearchGate was included as a source that researchers often used to share their work with other researchers via a technology-supported collaborative environment. Search terms were generated or adopted from keywords in relevant articles. The original search terms used were collaborative research team, faculty to faculty research networks, faculty research networks, adjunct faculty research networks, adjunct faculty collaborative research, online faculty research collaboration, faculty research teams collaboration. Further variations of these search terms included university or higher education faculty collaborative research teams, higher education faculty collaborative research teams, researcher collaborative networks, networks of researchers, research teams online, online faculty and publishing and teams, collaboration with graduate students, collaboration between faculty and undergraduate students, and collaboration between university faculty and graduate students.

\section{Criteria developed to judge data for fit}

The process of reviewing data for alignment to the identified problem was in accordance with H. M. Cooper's (1998) Step C. Literature inclusion during the review process comprised analysis of qualitative, quantitative, mixed-methods empirical research, theoretical and conceptual analyses, and commentaries, as well as literature reviews. The full article in English was required for inclusion; additionally, articles were evaluated as current (2012-2019), peer reviewed, and included in scholarly publications. The first search conducted in EBSCOhost was narrowed to exclude business, medicine, health, and science, where many technologysupported, collaborative studies were found. Further criteria defined higher education, humanities, social sciences, and adjunct faculty as populations of interest to the study where technology-supported collaborative research was less frequent. A second search conducted in EBSCOhost and ProQuest used the same terms adding higher education faculty while maintaining limiters. A third search was conducted at SAGE Knowledge journals. A fourth search was conducted on ResearchGate. Searches were repeated as new keywords were added. 


\section{Data Evaluation}

Articles were initially appraised and interpreted, as defined by H. M. Cooper's (1998) Step D, to be relevant and to the literature review purposes. The criteria were related to the study's intent and research questions. How teams communicated during the collaborative research process was indicated in each of the studies reviewed. Technology support for faculty collaborative research included conference calls (Zoom, WebEx, Skype), social media (Twitter, Facebook, Instagram, Google Classroom), networking via university specific sources, and communication (emails, instant messages). Team techniques for communication were included in each article. Not included were networking groups such as ResearchGate, LinkedIn, or others for community networking due to these platforms being less relevant to conducting research and primarily used for social communication (Jamali et al., 2014). Key search terms were gathered and included in subsequent searches which were further narrowed by exclusions, ultimately culminating in 113 articles as the population.

\section{Sample Selection Process}

Each of the 113 articles was reviewed for design inclusive of technology-supported collaboration, population, sample, and results. The abstract or entire article was reviewed to further validate articles for the study sample. From the list of 113 articles, 50 were selected for more intensive analysis based on consistent fit to criteria including topic of study inclusive of technology-supported collaboration, design, population, and results. Each team member collaborated in discussions to identify a final sample of eight articles after extensive review and discussion based on the same criteria which represented the best fit to meet the goals of this study. An additional complete literature search was conducted at 4 months and again at 8 months after the initial search. These subsequent searches confirmed no new empirical research had emerged.

\section{Appraise and Interpret Data Determined to be Relevant}

The literature review process, data evaluation, and analysis were conducted incorporating H. M. Cooper's (1998) Step D. Consistent with established criteria, selected articles focused on aspects of collaboration and networking within an institution of higher learning, among colleagues of separate institutions, or groups using technology via social networks for connecting with like-minded scholars. The approach was driven by the intent to learn how technology-supported collaborative research teams form and function within identified disciplines of higher education, humanities, and social sciences to reach the desired outcome of completing publishable research. Research team members were composed of full-time, part-time, or associate/adjunct faculty. Descriptive categories were developed for the initial analysis of each article: topic, research design, population, and results related to the research questions.

\section{Results of Analysis}

\section{Categorize, Assemble, and Present the Products}

The final steps in the process, data evaluation, and analysis were conducted incorporating H. M. Cooper's (1998) Step E. Content analysis of the eight sample articles abstracts was a final step to check the consistency of the team collaborative process. The review of eight journal article abstracts was conducted through the generation of a word cloud (see Figure 1) that supported the descriptive categories found based on a content analysis of articles selected for this study. Emergent categories from the team's collaborative analysis were compared with the frequent words found in the content analysis. The word cloud is a global representation based on the abstracts the journal articles. Although global in nature, the word cloud aligned with topics that were uncovered during the analysis of each article (see Tables 1-3). To assess frequencies, common variants of words were grouped together, including present and past tense, singular or multiples, or other variations of 
the same root word. The most frequent root words were as follows: research (42), collaborate (26), team (17), discipline (12), compare (eight), and international (seven).

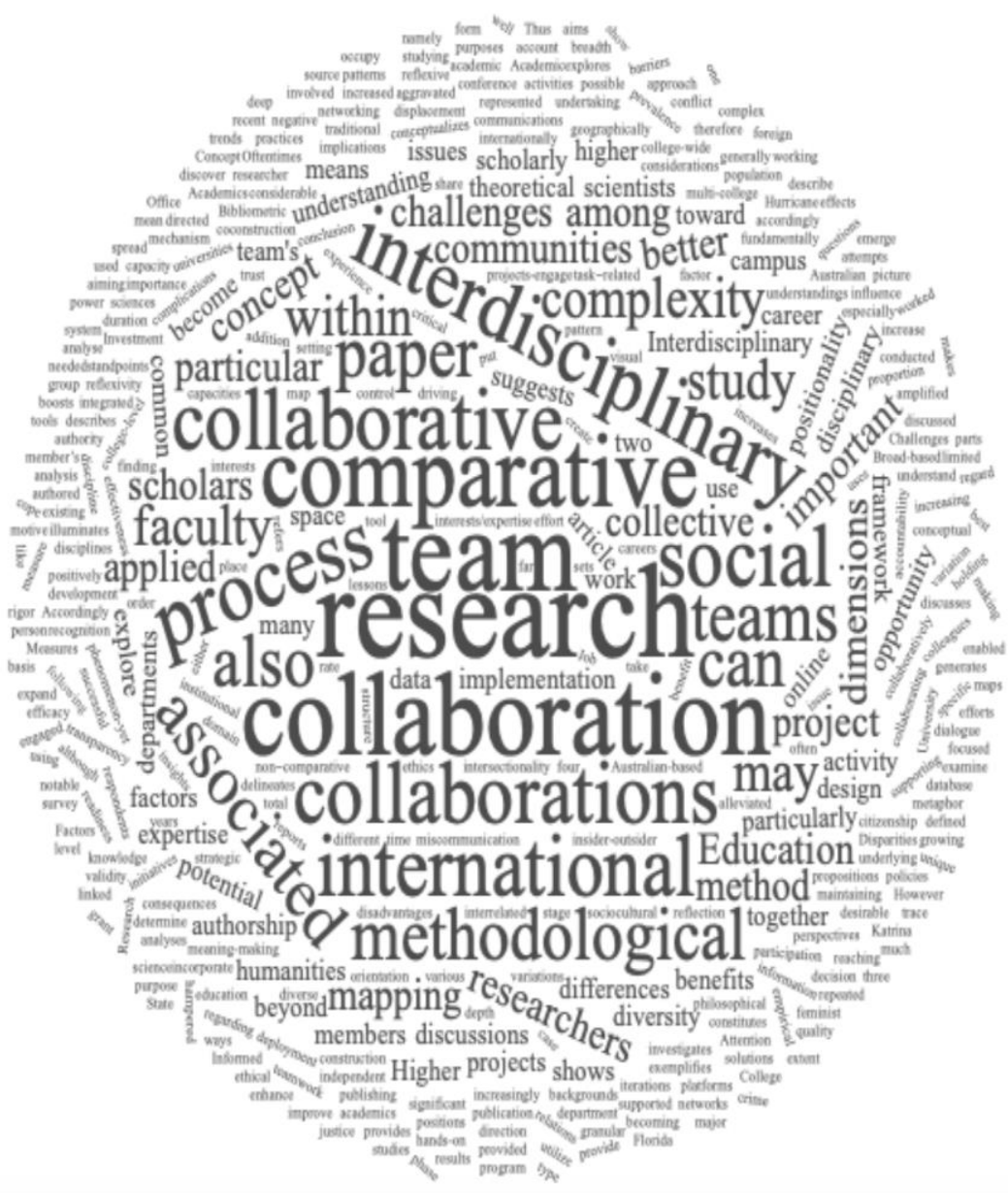

Figure 1. Selected Journal Articles'Abstract Content Word Frequency

Each article included in the study was categorized for topic, research design, population, and results. Categorical analysis allowed for grouping and regrouping articles in response to the research questions. Tables 1-3 show articles identified for responses to research questions and include author(s), title, publisher, research design, and population. A brief introduction highlights the key findings in response to each research question is provided. A summary and discussion of each article in response to the research questions follow the tables.

\section{Research Question 1}

Several descriptive categories emerged in response to Research Question 1, as noted in Table 1. Descriptive categories are formal (Novak et al., 2014) and informal networks (Pardee et al., 2017) based in the university setting as well as event-centered networks. An informal network is initiated by a shared interest in a specific phenomenon rather than supported by institutional agencies (Pardee et al., 2017) or is developed to study patterns of collaborative research within specific disciplines where collaboration is rare (Burroughs, 2017). 
Table 1. Formation of Collaborative Research Team Networks When Using Technologically Powered Connectivity

\begin{tabular}{|c|c|c|c|c|}
\hline Topic & Author(s) & Design & Population & Results \\
\hline $\begin{array}{l}\text { Formal university- } \\
\text { based network } \\
\text { systems }\end{array}$ & $\begin{array}{l}\text { Novak et al. } \\
\quad(2014)\end{array}$ & Content analysis & $\begin{array}{l}\text { Higher education } \\
\text { faculty at Florida } \\
\text { State University }\end{array}$ & $\begin{array}{l}\text { Faculty forums at Florida } \\
\text { State University succeed in } \\
\text { connecting collaborative } \\
\text { teams }\end{array}$ \\
\hline $\begin{array}{l}\text { Informal } \\
\text { university } \\
\text { network systems } \\
\text { based on shared } \\
\text { interests }\end{array}$ & $\begin{array}{l}\text { Burroughs } \\
(2017)\end{array}$ & $\begin{array}{l}\text { Bibliometric } \\
\text { analysis }\end{array}$ & $\begin{array}{l}\text { Four university } \\
\text { departments in the } \\
\text { humanities at a } \\
\text { single university }\end{array}$ & $\begin{array}{l}\text { Study of campus scholarly } \\
\text { networking to scrutinize } \\
\text { coauthorship and assess } \\
\text { readiness for team research } \\
\text { and deep collaboration } \\
\text { within four departments at a } \\
\text { single university }\end{array}$ \\
\hline $\begin{array}{l}\text { Formal event- } \\
\text { centered } \\
\text { networking }\end{array}$ & $\begin{array}{l}\text { Pardee et } \\
\text { al. (2017) }\end{array}$ & $\begin{array}{l}\text { Collective method; } \\
\text { integrated, } \\
\text { reflexive research } \\
\text { design }\end{array}$ & $\begin{array}{c}\text { Social sciences } \\
\text { faculty members at } \\
\text { a single university }\end{array}$ & $\begin{array}{l}\text { Researchers met face to face } \\
\text { or used technology to stay } \\
\text { connected; } \\
\text { research team responded to } \\
\text { Hurricane Katrina (prior to } \\
\text { this, the group was not } \\
\text { working collaboratively) }\end{array}$ \\
\hline
\end{tabular}

\section{Formal university-based network systems}

Novak et al. (2014) performed a focused analysis of university systems and networks to promote interdisciplinary research among faculty members. The intent was to bring faculty members together to meet and share information about current research projects and interests and ultimately increase production of published works. Faculty had access to existing networks and databases to find other individuals throughout the university who had similar research interests and expertise areas. Using network systems and faculty databases increased collaboration among faculty within the same colleges or across the university as interdisciplinary research teams.

\section{Formal event-centered university networks}

An interdisciplinary research network formed to conduct independent research on displaced survivors of Hurricane Katrina (Pardee et al., 2017). The researchers were 12 scholars who developed a network of collaboration and collective effort to research specific phenomena from independent viewpoints and disciplines, finding common themes across multiple studies, and various disciplines. The collaborative network added diverse voices to stories and accounts shared in Katrina's aftermath. Members evaluated studies from multiple perspectives and conducted internal peer-reviews of each study with high standards of transparency and accountability. The network spanned a 6-year period. Two annual teleconferences maintained group contact between face-to-face meetings. Teleconferences were used during the research process for formulating manuscripts.

\section{Informal university networks}

Analysis across departments in the humanities showed different collaboration levels between and within individual departments (Burroughs, 2017). The analysis included over 90 faculty members and 1,200 articles and indicated marked differences between departments within the same discipline. Authorship networking maps visually displayed the coauthorship relationships between and within departments. Collaborative networking structures existed within and between departments, and experienced faculty members and men were more likely to engage. Networking patterns indicated that a few individuals (eight out of 700 in the study) were vectors for research and collaborated more frequently. These frequent collaborators may play a 
pivotal role as initiators, engagers, or influencers in collaborative groups. Differences between departments, networks, and individual faculty members may contribute to depth of involvement in collaborative research.

\section{Subquestion 1}

Technology was identified as an important pathway to collaboration among online adjuncts (Schieffer, 2016). Adjunct faculty used databases to find other faculty with similar research interests (Novak et al., 2014). Larger networks were useful for sharing news but not for collaborative teaming on national or international research networks (Jamali et al., 2014). Schieffer (2016) described technologies to support collaboration (see Table 2) including networking via university specific sources, communication (emails, instant messaging), virtual communications (Zoom, WebEx, Skype), and social media (Twitter, Facebook, Instagram, Google Classroom).

Table 2. Use of Technology to Support the Generation of New Research Knowledge

\begin{tabular}{|c|c|c|c|c|}
\hline Topic & Author(s) & Design & Population & Results \\
\hline \multicolumn{5}{|l|}{$\begin{array}{l}\text { Online } \\
\text { communities/ } \\
\text { social media }\end{array}$} \\
\hline $\begin{array}{l}\text { As an instrument } \\
\text { to foster } \\
\text { collaborative } \\
\text { research }\end{array}$ & $\begin{array}{l}\text { Jamali et } \\
\text { al. (2014) }\end{array}$ & Mixed methods & $\begin{array}{l}1,350 \text { Social science } \\
\text { faculty members in } \\
\text { networking } \\
\text { communities }\end{array}$ & $\begin{array}{l}\text { Scholars use social media for } \\
\text { information seeking and } \\
\text { networking, not forming } \\
\text { collaborative research teams }\end{array}$ \\
\hline $\begin{array}{l}\text { As a networking } \\
\text { and } \\
\text { collaboration } \\
\text { instrument } \\
\text { among adjuncts }\end{array}$ & $\begin{array}{l}\text { Schieffer } \\
(2016)\end{array}$ & Qualitative & $\begin{array}{l}\text { Remote adjunct } \\
\text { faculty; for-profit } \\
\text { and nonprofit } \\
\text { institutions }\end{array}$ & $\begin{array}{l}\text { Focus on collaboration for } \\
\text { professional/academic } \\
\text { development and a means to } \\
\text { publish research }\end{array}$ \\
\hline $\begin{array}{l}\text { Research interests } \\
\text { database }\end{array}$ & $\begin{array}{l}\text { Novak et al. } \\
\quad(2014)\end{array}$ & Content analysis & $\begin{array}{l}\text { Florida State } \\
\text { University higher } \\
\text { education faculty }\end{array}$ & $\begin{array}{c}\text { The university database } \\
\text { supported faculty-facilitated } \\
\text { collaboration }\end{array}$ \\
\hline
\end{tabular}

\section{Collaboration among adjuncts}

Schieffer (2016) conducted a phenomenological investigation of 10 online adjunct faculty members at various institutions of higher learning. The opportunity to collaborate with other faculty in virtual environments was essential to professional development, scholarship, and fellowship. Virtual teaming and online collaboration could be elements of successful scholarly practices for remote faculty members. Recommendations included that online adjunct faculty use university distance learning platforms, email, chat rooms, or other provided technology. A further recommendation was the need for effective institutional leadership to support and foster adjunct faculty involvement and development in various online collaborative opportunities.

\section{A database to find others with similar research interests}

The Florida State University Office of Research developed a database for faculty to find potential partners for collaborative research (Novak et al., 2014). An initial evaluation showed additional database fields needed to highlight specific faculty expertise and ease the process of formulating collaborative teams with common research interests. Once the database was more robust, faculty members were able to successfully identify, locate, and engage with faculty who shared common research interests. During the inaugural implementation, seven research proposals were submitted, three of which were from interdisciplinary teams. An interdisciplinary research conference yielded a high level of interest, with more than $50 \%$ of faculty willing to integrate interdisciplinary collaboration for research projects. The researchers proposed further database development and accessibility may result in greater collaboration, communication, and research across faculty, including formation of interdisciplinary teams. 


\section{Information sharing but not research collaboration}

A mixed-methods study investigated whether faculty were using national or international networks to collaborate on research (Jamali et al., 2014). The findings showed researchers used the large networks, such as ResearchGate, to share information and gain insights into developments in their field. Another important function was to promote and disseminate newly published research. Results indicated very little collaborative research in the online research networks.

\section{Subquestion 2}

Several categories emerged in response to Subquestion 2: institutional leadership, collective team leadership, attributes of successful teams, and social presence (see Table 3). Institutional leadership was essential for teams to function effectively within larger organizations such as departments, universities, or interagency partnerships (Schieffer, 2016). Institutional and collective leadership is needed within the teams to establish rigor, transparency, efficacy, and accountability (Pardee et al., 2017) and to maintain a sense of commitment (DeGeorge-Walker \& Tyler, 2014). Experience in collective research was another attribute of successful teams (Woolley et al., 2015). Social presence was experienced as camaraderie, trust, and social connections and was another significant quality for team success (Schieffer, 2016). Maintaining balance between the degree of disciplinary difference and equity of academic control were important attributes of successful teams (Siemens et al., 2014).

\section{Attributes of successful teams: Professional and personal accountability}

Professional and personal accountability enhanced the collaboration process among team members (Pardee et al., 2017; Woolley et al., 2015). Moreover, mindful collaboration and purposeful communication between diverse scholars shaped critical discussions regarding research, applied ethics, and common themes across the work (Pardee et al., 2017). The collaborative process resulted in a high level of integration, producing a new strategy for scholarly engagement and standards for research accountability. These attributes were associated with successful teams. Teams must recognize that group effort, accountability, and working towards a common goal are more powerful than independent research. Successful teams collaborate to set ground rules for achievement in a continual, peer review process, which is required to promote higher standards, rigor, transparency, and efficacy within the collective (Pardee et al., 2017). Findings, as suggested by Pardee et al. (2017), indicated (a) the role and importance of internal feedback when writing and conducting research; (b) feedback by members of the collective insured justification of methodological, theoretical, ethical, political, and personal decisions to their peers; (c) holding members to hypertransparency and a higher standard than a journal review led to more authentic research for the collective and individual scholar.

\section{Attributes of successful teams: Diversity}

Effective interdisciplinary collaboration was based on level of research experience, number of previous academic positions held both within the home country and as international faculty and guest lecturers, and frequency of conducting research (Woolley et al., 2015). Diverse experiences laid a rich foundation for greater collaboration among researchers. Global connectivity with scholars from other cultural, social, and academic backgrounds had a favorable impact on the scope and degree of interdisciplinary research collaboration.

\section{Technology powers online collaboration}

Kosmützky (2018) focused on the role of technology and online collaboration to produce new knowledge through research. The study explored techniques and strategies of successful collaborative researchers working across geographic distance and cultural diversity. International research teams used technology to bring together highly trained research professionals to resolve a variety of problems. Scientific investigations, which might not otherwise take place, were successful because collaborative teaming was made possible by technology. 
Table 3. Attributes and Organizational Frameworks of Successful Collaborative Research Teams

\begin{tabular}{|c|c|c|c|c|}
\hline Topic & Author(s) & Design & Population & Results \\
\hline \multirow{2}{*}{$\begin{array}{l}\text { The collective } \\
\text { team } \\
\text { recognized a } \\
\text { common goal } \\
\text { was more } \\
\text { powerful than } \\
\text { independent } \\
\text { goals }\end{array}$} & \multirow[t]{2}{*}{$\begin{array}{l}\text { Pardee et al. } \\
\quad(2017)\end{array}$} & \multirow[t]{2}{*}{$\begin{array}{l}\text { Collective } \\
\text { method; } \\
\text { integrated, } \\
\text { reflexive process }\end{array}$} & \multirow[t]{2}{*}{$\begin{array}{l}\text { Social Sciences } \\
\text { faculty member at a } \\
\text { single university }\end{array}$} & $\begin{array}{l}\text { An all-female collective, } \\
\text { cultivated internal peer-reviewed } \\
\text { research process and produced } \\
\text { higher accountability standards } \\
\text { than traditional journal } \\
\text { reviewers. }\end{array}$ \\
\hline & & & & $\begin{array}{l}\text { Established normative behavior } \\
\text { and language included critical } \\
\text { discussions regarding research, } \\
\text { applied ethics, and common } \\
\text { themes across their work. }\end{array}$ \\
\hline $\begin{array}{l}\text { Need for } \\
\text { collaboration } \\
\text { between } \\
\text { diverse } \\
\text { researchers }\end{array}$ & $\begin{array}{l}\text { Kosmützky } \\
\text { (2018) }\end{array}$ & $\begin{array}{l}\text { Review of } \\
\text { empirical } \\
\text { research articles } \\
\text { to clarify and } \\
\text { expand } \\
\text { conceptual } \\
\text { understanding }\end{array}$ & $\begin{array}{c}\text { Articles by } \\
\text { geographically } \\
\text { distributed social } \\
\text { sciences research } \\
\text { teams }\end{array}$ & $\begin{array}{l}\text { Diverse collaborative teams and } \\
\text { methods are required to address } \\
\text { and study 21st-century } \\
\text { complexity; } \\
\text { international coauthored articles } \\
\text { instead of regional teams to } \\
\text { conduct research }\end{array}$ \\
\hline $\begin{array}{l}\text { Research } \\
\text { collaborators } \\
\text { require } \\
\text { institutional } \\
\text { and collective }\end{array}$ & $\begin{array}{l}\text { Schieffer } \\
\text { (2016) }\end{array}$ & Qualitative & $\begin{array}{l}\text { Remote adjunct } \\
\text { faculty; for-profit } \\
\text { and nonprofit } \\
\text { institutions }\end{array}$ & $\begin{array}{l}\text { Categories: (a) need to engage in } \\
\text { scholarship/research, (b) } \\
\text { motivation to join collaborative } \\
\text { teams, (c) pressure to collaborate } \\
\text { as a means to publish }\end{array}$ \\
\hline $\begin{array}{l}\text { team } \\
\text { leadership }\end{array}$ & & & & $\begin{array}{l}\text { Recommendation: institutions } \\
\text { provide framework, } \\
\text { organization, and structure for } \\
\text { online adjuncts to find } \\
\text { collaboration }\end{array}$ \\
\hline $\begin{array}{l}\text { Successful } \\
\text { distributed } \\
\text { teams include } \\
\text { balanced and } \\
\text { diverse } \\
\text { experience }\end{array}$ & $\begin{array}{l}\text { Woolley et } \\
\text { al. (2015) }\end{array}$ & $\begin{array}{l}\text { Self-report } \\
\text { surveys }\end{array}$ & $\begin{array}{l}\text { Social sciences } \\
\text { faculty }\end{array}$ & $\begin{array}{l}\text { Diverse experience, duration } \\
\text { contribute to quality } \\
\text { collaborative participation with } \\
\text { fellow scholars in the social } \\
\text { sciences }\end{array}$ \\
\hline $\begin{array}{l}\text { Concept } \\
\text { mapping to } \\
\text { build research } \\
\text { team } \\
\text { capacities }\end{array}$ & $\begin{array}{l}\text { DeGeorge- } \\
\text { Walker \& } \\
\text { Tyler (2014) }\end{array}$ & Case study & $\begin{array}{c}\text { The Capacity } \\
\text { Building Research } \\
\text { Network- } \\
\text { multidisciplinary } \\
\text { educational team at } \\
\text { Australian university } \\
(N=17 \text { researchers })\end{array}$ & $\begin{array}{l}\text { Collaborative concept mapping is } \\
\text { effective for capacity building; it } \\
\text { enabled shared exploration, } \\
\text { articulation, and negotiation of } \\
\text { intentions and opportunities; } \\
\text { mapping generated an artifact of } \\
\text { purpose whose focused intent } \\
\text { offers a shared construct for } \\
\text { critical reflection }\end{array}$ \\
\hline $\begin{array}{l}\text { Organizational } \\
\text { frameworks to } \\
\text { build research } \\
\text { team } \\
\text { capacities }\end{array}$ & $\begin{array}{l}\text { Siemens et } \\
\text { al. (2014) }\end{array}$ & $\begin{array}{l}\text { A conceptual } \\
\text { framework for } \\
\text { collaborative } \\
\text { teams }\end{array}$ & $\begin{array}{l}\text { Collaborative digital } \\
\text { humanities team } \\
\text { (initial team: } \\
\text { English professor, } \\
\text { computer science } \\
\text { graduate student, } \\
\text { management } \\
\text { scholar) }\end{array}$ & $\begin{array}{l}\text { A collaborative space framework } \\
\text { was useful to understand and } \\
\text { develop effective collaborative } \\
\text { research teams based on } \\
\text { similarity of academic fields }\end{array}$ \\
\hline
\end{tabular}




\section{Leadership is required: Social presence is desired}

Higher education institutional leadership is essential to fostering collaborative research (Schieffer, 2016). Without leadership, remote online faculty experience isolation and struggle to participate in collaborative research. Remote faculty often face feelings of isolation, disengaged feelings, and experienced obstacles to creating collaborative professional relationships, which were barriers to working with other faculty across institutions. In contrast, online faculty desired and benefitted from institutional leadership to support online collaborative endeavors. Technology supported research collaboration reduced adjunct faculty seclusion and increased a sense of belonging to the university, department, and the research community. One critical quality for team success was social presence, described as experiences of camaraderie, trust, and social connections. Online faculty were interested in opportunities to conduct collaborative research supported by technology and experienced professional academic development leading to positive change, research expertise, and achievement, when institutional leadership and assistance was provided for scholarly research.

\section{Collective team leadership: Concept mapping to frame and balance collaborative space}

Siemens et al. (2014) presented a conceptual model for developing effective collaborative research teams. The concept mapping model was derived from investigating research team operations in the Digital Humanities. The team faced challenges from the disparate academic disciplines, varied knowledge, and different levels of technological expertise. The investigation revealed unique group attributes which resulted in the Framework of the Collaboration Space, grounded in two dimensions: (a) degree of disciplinary difference and (b) equity of academic control. As collaborative teams developed, finding the proper balance along these dimensions may lead to success. Teams that acknowledge differences, build trust, and find strength in the contributions of all members, are most likely to find success. The use of technology as a means for communication seems to be an essential strategy for successful team outcomes.

\section{Collective team leadership to develop capacity}

DeGeorge-Walker and Tyler (2014) applied collaborative concept mapping (CCM) to conceptualize how one active research team expanded their research capacity as a unit. CCM fostered a sense of shared exploration, commitment to the research goals, and motivation for future collaborative endeavors. CCM techniques allowed team members to connect with the research via internalization of key concepts, development of personal ownership in the research process, and creation of a collective purpose for the team. Although these findings cannot be generalized to other teams, the indication is that CCM applications are one strategy for developing capacity within collaborative research teams.

\section{Summary of Analysis}

Higher education, social sciences, humanities, and adjunct faculty members value technologically supported connections (Schieffer, 2016) and opportunities for research through technology (Burroughs, 2017; Novak et al., 2014; Pardee et al., 2017). Team success depends on institutional leadership in the organizational context (Schieffer, 2016) and internal team leadership to support commitment (DeGeorge-Walker \& Tyler, 2014), establish rigor, transparency, and accountability (Pardee et al., 2017). Successful teams experienced high levels of social connection (Schieffer, 2016), include members experienced in collaborative research (Woolley et al., 2015) and maintain a balanced level of academic control in multidisciplinary teams (Siemens et al., 2014). Formal university research networks are established when faculty members found others with similar research interests in university maintained databases (Novak, et al., 2014). Both formal and informal university research teams in collaborative settings (Burroughs, 2017; Novak et al., 2014), or arising out of a shared interest in an event (Pardee et al., 2017) used technology to support networking via university specific sources, communication (emails, instant messages), virtual communications (Zoom, WebEx, Skype), and social media (Twitter, Facebook, Instagram, Google Classroom). 


\section{Discussion}

Faculty members used technology to identify and acquire new opportunities for scholarship and professional academic development. Faculty might use databases to find collaborative research partners (Novak et al., 2014) or use available technology to facilitate collaboration and communication (Schieffer, 2016). Virtual environments broaden faculty engagement and fellowship (Schieffer, 2016) and were instrumental in collaborative research. Collaboration for research purposes happens outside of large, national research networks that are primarily used for exchanging information and networking across institutions and national boundaries (Jamali et al., 2014). Technologies useful for collaborative research include conference calls (Zoom, WebEx, Skype), social media (Twitter, Facebook, Instagram, Google Classroom), communication (emails, instant messages), and networking via university specific resources (Schieffer, 2016).

Several descriptive categories emerged as attributes of successful research teams, including leadership at institutional and collective team levels. Institutional leadership was essential for the team to function effectively within larger organizations such as departments, universities, or interagency collaborative partnerships (Schieffer, 2016). Institutional and collective leadership establishes rigor, transparency, efficacy, accountability (Pardee et al., 2017), and maintains a sense of commitment (DeGeorge-Walker \& Tyler, 2014). These descriptive aspects of successful collaborative teams are consistent with insights Leibowicz (2014) acknowledged as necessary for understanding and fostering professional academic development.

Previous collective research experience was an attribute of successful teams (Woolley et al., 2015) indicating that experience improves practice. Another critical quality for team success was social presence, described as camaraderie, trust, and social connections (Schieffer, 2016). Maintaining balance between the degree of disciplinary difference and equity of academic control is important for successful teams (Siemens et al., 2014). Successful teams include individuals with specific social and professional characteristics (DeGeorge-Walker \& Tyler, 2014; Schieffer, 2016; Siemens et al., 2014; Woolley et al., 2015). These characteristics included a sense of trust in one another and social presence.

\section{Significance}

Technology powered, national or international, multidisciplinary, collaborative teams are a fourth age research phenomenon when complex 21st-century problems require sophisticated levels of knowledge (Kosmützky, 2018). These teams cross many cultural, disciplinary, and geographical boundaries to engage multiple problem-solving perspectives. Such teams are catalysts for robust professional academic development in a technologically driven world. Professional academic developers might note that collaborative researchers gain benefits from collegial relationships, acquire stronger research skills and reach higher achievement levels. Numbers of collaborative research teams are increasing as understanding of benefits grows (Siemens et al., 2014). Successful research teams add value to university and individual faculty standings while increasing sense of community among remote and adjunct faculty (Schieffer, 2016).

\section{Recommendations}

Collaborative team research should be investigated further to understand and promote cross-discipline and cultural collaboration potential for research and professional academic development possibilities. Gaps in the literature included team development, opportunities for women, collaborative research networks, and faculty development. More research is needed into the vectors that initiate construction, development, and attributes of successful research teams. Interviews with frequent collaborators might provide interesting insights. More could be learned about collaborative research opportunities for women, who have fewer opportunities than men in more traditional university settings. Tracking formal and informal research networks might uncover structures and resources needed for success. Collaborative research teams may have opportunities to generate new insightful scholarship during challenging moments in history by including diverse team dynamics when 
investigating a topic from multiple perspectives. Ultimately, professional academic development hinges upon the inherent, everlasting cycle of producing and consuming knowledge making everything else possible. Collaborative research teams represent a project-based learning opportunity for faculty professional academic development that should be explored further.

\section{Conclusion}

Despite 21st-century technology to support collaborative research across multiple boundaries, few online research teams investigate contemporary issues in higher education pedagogies, social sciences, and humanities or for adjuncts. Literature on collaborative research in all higher education disciplines is limited (Gast et al., 2017). The collaborative research process of adjuncts in all fields of higher education is rarely studied (Schieffer, 2016). In addition, higher education pedagogies, the social sciences, and the humanities urgently need more exploratory research into the benefits of collaborative team scholarship. The hope is that our review adds to the discussion of possibilities for future work. A promising opportunity exists for professional academic development through team-based research (Leibowicz, 2014) in these fields. Collaborative research teams offer valuable professional academic development opportunities especially for online faculty (full time or adjunct) working in remote, isolated environments where joining a team could create a sense of an academic and scholarly community (Schieffer, 2016).

\section{References}

American Association of University Professors. (2018). Background facts on contingent faculty positions. https://www.aaup.org/issues/contingency/background-facts

Anderson, S., Allen, P., \& Peckham, S. (2008). Asking the right questions: Scoping studies in the commissioning of research on the organization and delivery of health services. Health Research Policy and Systems, 6(7), 1-12.

Avella, J. T., Kebritchi, M., Nunn, S. G., \& Kanai, T. (2016). Learning analytics methods, benefits, and challenges in higher education: A systematic literature review. Online Learning, 2O(2), 13-29. https://files.eric.ed.gov/fulltext/EJ1105911.pdf

Boyer, E. (1996). From scholarship reconsideration to scholarship assessed. Quest, 48, 129-131.

Burroughs, J. M. (2017). No uniform culture: Patterns of collaborative research in the Humanities. Portal:Libraries and the Academy, 17(3), 507-527. https://doi.org/10.1353/pla.2017.0032

Caruth, G. D., \& Caruth, D. L. (2013). Adjunct faculty: Who are these unsung heroes of academe? Current Issues in Education, 16(3), 1-11. https://cie.asu.edu/ojs/index.php/cieatasu/article/view/1269

Cheruvelil, K. S., Soranno, P. A., Weathers, K. C., Hanson, P. C., Goring, S. J., Filstrup, C. T., \& Read, E. K. (2014). Creating and maintaining high-performing collaborative research teams: The importance of diversity and interpersonal skills. Frontiers in Ecology and the Environment, 12(1), 31-38. https://doi.org/10.1890/130001

Cooper, H. M. (1985). A systematic examination of the literature review and knowledge synthesis activities (Grant No. NIE-G-82-0022). National Institute of Education.

Cooper, H. M. (1986). Literature-searching strategies of integrative research reviewers. Knowledge, 8(2), 372-383. https://doi.org/10.1177/107554708600800217

Cooper, H. M. (1988). Organizing knowledge syntheses: A taxonomy of literature reviews. Knowledge in Society, 1(1),104. https://doi.org/10.1007/bfo3177550 
Cooper, H. M. (1998). Applied social research methods, Vol. 2. Synthesizing research: A guide for literature reviews (3rd ed.). Sage.

Cooper, S., Cant, R., Kelly, M., Levett-Jones, T., McKenna, L., Seaton, P., \& Bogossian, F. (2019). An evidencebased checklist for improving scoping review quality. Clinical Nursing Research. Advance online publication. https://doi.org/10.1177/1054773819846024

Dailey-Hebert, A., Norris, V. R., Mandernach, B. J., \& Donnelli-Sallee, E. (2014). Expectations, motivations, and barriers to professional development: Perspectives from adjunct instructors teaching online. The Journal of Faculty Development, 28(1), 67-82.

DeGeorge-Walker, L., \& Tyler, M. (2014). Collaborative concept mapping: Connecting with research team capacities. Education Research International, 2014, 836068. https://doi.org/10.1155/2014/836068

Eddy, P. L., \& Garza Mitchell, R. L. (2012). Faculty as learners: Developing thinking communities. Innovative Higher education, 37(4), 283-296. https://doi.org/10.1007/s10755-011-9202-Z

Falci, C., Zippel, K., \& Dejordy, R. (2014). Gender differences in faculty research networks within and outside a university. Roundtable presented at the 109th ASA Annual Meeting, August 16-19, San Francisco, CA.

Gast, I., Schildkamp, K., \& van der Veen, J. T. (2017). Team-based professional development interventions in higher education: A systematic review. Review of Educational Research, 87(4), 736-767. https://doi.org/10.3102/003465431770430

Jamali, H. R., Russell, B., Nicholas, D., \& Watkinson, A. (2014). Do online communities support research collaboration? Aslib Proceedings, 66(6), 29-42. https://doi.org/10.1108/AJIM-08-2013-0072

Kebritchi, M., \& Hirumi, A. (2008). Examining the pedagogical foundations of modern educational computer games. Computers \& Education, 51, 1729-1743. https://doi.org/10.1016/j.compedu.2008.05.004

Kosmützky, A. (2018). A two-sided medal: On the complexity of international comparative and collaborative team research. Higher Education Quarterly, 72(4), 314-331. https://doi.org/10.1111/hequ.12156

Leibowicz, B. (2014). Reflections on research and practice: What is in a name? International Journal for Academic Development, 19(4), 357-360. https://doi.org/10.1080/1360144X.2014.969978

Matthews, K., Lodge, J., \& Bosanquet, A. (2014) Early career academic perceptions, attitudes and professional development activities: Questioning the teaching and research gap to further academic development. International Journal for Academic Development, 19(2), 112-124. https://doi.org/10.1080/1360144X.2012.724421

Mayring, P. (2000). Qualitative content analysis. Forum: Qualitative Social Research, 1(2). https://doi.org/10.17169/fqs-1.2.1089

Misra, J., Smith-Doerr, L., Dasgupta, N., Weaver, G., \& Normanly, J. (2017). Collaboration and gender equity among academic scientists. Social Sciences, 6(1), 25. https://doi.org/10.3390/socsci6010025

Novak, E., Zhao, W., \& Reiser, R. A. (2014). Promoting interdisciplinary research among faculty. Journal of Faculty Development, 28(1), 19-24.

Pardee, J. W., Fothergill, A., Weber, L., \& Peek, L. (2017). The collective method: Collaborative social science research and scholarly accountability. Qualitative Research, 18(6), 671-688. https://doi.org/10.1177/1468794117743461

Renner, J. (2017). Engaging TBR faculty in online research communities and emerging technologies. Journal of Learning in Higher Education,13(1), 33-44. https://eric.ed.gov/?id=EJ1139696

Schieffer, L. (2016). The benefits and barriers of virtual collaboration among online adjuncts. Journal of Instructional Research, 5,109-125. https://eric.ed.gov/?id=EJ1127636 
Siemens, L., Liu, Y., \& Smith, J. (2014). Mapping disciplinary differences and equity of academic control to create a space for collaboration. Canadian Journal of Higher Education Revue, 44(2), 49-67.

Stewart, B. E. (2015). In abundance: Networked participatory practices as scholarship. International Review of Research in Open and Distance Learning, 16(3), 318-340. http://www.irrodl.org/index.php/irrodl/article/view/2158/3343

Turner, R., Brown, T., \& Edwards-Jones, A. (2014) "Writing my first academic article feels like dancing around naked”: Research development for Higher Education lecturers working in further education colleges, International Journal for Academic Development, 19(2), 87-98. https://doi.org/10.1080/1360144X.2013.792729

Vabø, A. A., Alvsvåg, A., Kyvik, S., \& Reymert, I. (2016). The establishment of formal research groups in Higher Education institutions. Nordic Journal of Studies In Educational Policy, 2(2/3), 1-11. https://doi.org/10.3402/nstep.v2.33896

Woolley, R., Sánchez-Barrioluengo, M., Turpin, T., \& Marceau, J. (2015). Research collaboration in the social sciences: What factors are associated with disciplinary and interdisciplinary collaboration? Science and Public Policy, 42(4), 567-582. https://doi.org/10.1093/scipol/scu074

The Higher Learning Research Communications (HLRC), is a peer-reviewed, online, interdisciplinary journal indexed in Scopus, ERIC, JGATE and Directory of Open Access Journals (DOAJ). It is an open access journal with an international focus published by Walden University, USA. Its aim is to disseminate both high quality research and teaching best practices in tertiary education across cultures and disciplines. HLRC connects the ways research and best practice contribute to the public good and impact the communities that educators serve. $H L R C$ articles include peer-reviewed research reports, research briefs, comprehensive literature reviews, and books reviews. 